\title{
ANALYSIS OF BULGARIAN REGULATIONS FOR HEAT TRANSFER OF BUILDINGS
}

\author{
Ivan Binev \\ Trakia University, Faculty of Technics and Technology \\ Graf Ignatiev № 38, 8602, Yambol, Bulgaria, e-mail: jbbinev@abv.bg
}

\begin{abstract}
The report provides an overview of the regulatory requirements for heat transfer coefficients in the building envelope according to the regulations in the Republic of Bulgaria from 1964 to 2016. The importance of heat transfer coefficients of enclosing structures of buildings is discussed that affect insulation provided in the energy audit which does not qualify after renovation of the building, due to changes in legislation. The discrepancy of the reference values of these coefficients and the real after implementation of energy saving measures can be implemented with the prior increase the requirements in the energy efficiency assessment in comparison with the standards in the ordinance. Keywords: heat transfer coefficient, energy conservation measures, energy consumption, heated area, heated space.
\end{abstract}

\section{INTRODUCTION}

With increasing requirements to the characteristics of living comfort increases and the need for the use of increasingly large amounts of energy, a process that increases our dependence on energy sources themselves. On the other hand, rising energy consumption leads to radical changes in the world around us, the effect is both constructive and destructive.

In our country, the majority of public buildings - schools, kindergartens, hospitals and others are municipal and state property. Reducing the cost of heating is an important and urgent task, as this will ease the financing of these institutions of state and municipal budgets.

The steps to convert these buildings into energy efficient and adapt their properties in accordance with the statutory requirements for energy efficiency under the Energy Efficiency Act and the regulations for its implementation are:

- Preparation of energy efficiency testing and prescription needed ESM in accordance with the statutory requirements for energy efficiency;

- Design stage;

- Tender study of financial instruments;

- Investment;

- Assignment;

- Monitoring and evaluation of investment [3, 4].

Reducing heat loss through the surrounding structures and elements of buildings is a major energy saving measure enshrined in any energy efficiency project.

Today, depending on the local climate and local energy needs to reduce these losses are applied certain architectural techniques that guarantee high energy efficiency and high standard of visual, thermal and healthy comfort in spaces where implemented various human activities [10].

The aim of the publication is a review and analysis of the legislation in the Republic of Bulgaria regulating heat transfer through the building envelope. 


\section{REGULATORY REQUIREMENTS TO THE HEAT TRANSFER THROUGH THE DENSE SURROUNDING STRUCTURES AND BUILDING ELEMENTS}

Legislation dealing with thermal requirements of buildings in the Republic of Bulgaria changed several times over the years, complying with the existing conditions at the time of delivery of energy sources. The low prices of these sources by the end of the 1970s of the twentieth century, had its impact on the heat transfer properties of buildings and therefore the designed heating systems and radiators in them.

The ensuing energy crisis affect significantly the regulatory framework and design solutions. This resulted in improved heat transfer characteristics. The process of adjustment of the technical regulations relating to the design of the thermal insulation of buildings and the characteristics of construction products used, began in the early 1960s of the twentieth century (Table 1) $[1,2,5,8,9]$.

Table 1. Regulatory acts and field of application

\begin{tabular}{|c|c|}
\hline Name of the normative act and field of application & $\begin{array}{c}\text { Year of } \\
\text { publication }\end{array}$ \\
\hline $\begin{array}{l}\text { Temporary instruction design and implementation of the thermal insulation in building } \\
\text { construction (in heated residential, public and industrial buildings) }\end{array}$ & 1960 \\
\hline $\begin{array}{l}\text { Thermal insulation in building construction. Design standards (in heated residential, } \\
\text { public and industrial buildings) }\end{array}$ & $\begin{array}{l}1964 \\
1969 \\
1977\end{array}$ \\
\hline Design standards of thermal insulation of buildings & $\begin{array}{l}1980 \\
1987\end{array}$ \\
\hline Ordinance №1 for the design of insulation of buildings & 1999 \\
\hline Ordinance №7 on heat and energy savings in buildings & 2004 \\
\hline Ordinance №7 energy efficiency, heat and energy savings in buildings & 2009 \\
\hline Ordinance №7 for energy efficiency in buildings & 2015 \\
\hline
\end{tabular}

In 1981, experts from NISI after analyzes of heat transfer performance of existing buildings, built to 1980 found that much of the surrounding walls of buildings in our country do not meet the requirements of even the acting then heat engineering standards. Today these buildings to existing regulations are "times" energy-inefficient [10].

In 1987 are introduced regulations which increased by about $35-40 \%$ of thermal requirements and determine generalized heat transfer coefficient [2].

Table 2. Normative values of coefficients of thermal conductivity of the surrounding structures and elements

\begin{tabular}{|c|c|c|c|c|c|c|c|c|c|c|}
\hline \multirow{3}{*}{$\begin{array}{l}\text { Type of } \\
\text { building } \\
\text { envelope }\end{array}$} & \multicolumn{10}{|c|}{ Heat transfer coefficient $K, W / m^{2} K$} \\
\hline & \multicolumn{2}{|c|}{$1964-1980$} & \multicolumn{2}{|c|}{ 1980-1987 } & \multicolumn{2}{|c|}{ 1987-1999 } & \multirow{2}{*}{$\frac{1999-2004}{K_{\max }}$} & \multirow{2}{*}{$\frac{2004-2009}{K_{\max }}$} & \multirow{2}{*}{$\frac{2009-2015}{K_{\max }}$} & \multirow{2}{*}{$\frac{\text { after } 2015}{K_{\max }}$} \\
\hline & from & to & from & to & from & to & & & & \\
\hline $\begin{array}{c}\text { Outer walls } \\
\text { single layer } \\
\text { (brick, } \\
\text { concrete) }\end{array}$ & 1,26 & 1,72 & 1,07 & 1,46 & 0,89 & 1,1 & \multirow{2}{*}{0,5} & \multirow{2}{*}{0,5} & \multirow[b]{2}{*}{0,35} & \multirow[b]{2}{*}{0,28} \\
\hline $\begin{array}{c}\text { Three layer } \\
\text { external } \\
\text { walls } \\
\text { (panels) }\end{array}$ & 1,05 & 1,43 & 0,78 & 1,06 & 0,45 & 0,59 & & & & \\
\hline Roofs & 0,97 & 1,67 & 0,9 & 1,15 & 0,48 & 0,65 & 0,35 & 0,35 & 0,28 & 0,25 \\
\hline $\begin{array}{c}\text { Floors over } \\
\text { basement }\end{array}$ & 0,81 & 1,1 & 0,64 & 0,88 & 0,7 & 0,95 & 0,5 & 0,5 & 0,5 & 0,5 \\
\hline
\end{tabular}




\section{IRTIL $\langle>$}

Ipplied Resseirlores in Technics, Technologies and Educration

Journal of the Faculty of Technics and Technologies, Trakia University https://sites.google.com/a/trakia-uni.bg/artte/

The requirement for making of thermal efficiency and calculating the minimum thickness of insulation was introduced in 1999. Then promulgated in the State Gazette and minimum coefficient of the building envelope [7].

In order to implement the EU directives in the Republic of Bulgaria adopted Decree №7 2004 (amend. 2009, 2010, 2013., 2015). Energy efficiency, heat and energy savings in buildings.

Ordinance complies with Directive 2002/91/ EC. Main criteria for the consumption of energy and heat for residential and non-residential buildings is the coefficient of heat transfer through the building envelope elements [5]. The maximum values of heat transfer coefficient Umax, $\mathrm{W} / \mathrm{m}^{2} \mathrm{~K}$ in building structures and elements for premises in buildings with calculation temperature indoor air $\theta_{\mathrm{i}}=20^{\circ} \mathrm{C}$ under "Insulation in construction.

"Design standards" from 1964, 1969 and 1977 as well as Design standards of thermal insulation of buildings" from 1980 and 1987 are presented in Table 2. [1, 2, 5, 7, 8].

For the period from 1980 to 1999 rates of heat transfer through building structures and elements in buildings are divided into two groups:

- For residential, hospitals and social care institutions, kindergartens, hotels and hostels;

- For schools, dispensaries and ambulatory-polyclinic institutions [2, 7, 8].

Presented in the table coefficients of thermal conductivity refer to schools, dispensaries and ambulatory-polyclinic institutions. From 1964 to 1999 heat transfer coefficients presented in the table are different computing winter temperature [2, 7, 8].

According to Ordinance №7 on heat and energy savings in buildings by 2004 normative values of the coefficient of thermal conductivity, $\mathrm{U}, \mathrm{W} / \mathrm{m}^{2} . \mathrm{K}$ are buildings with regulations internal temperature $\theta_{i} \geq 19^{\circ} \mathrm{C}$.

In amending Ordinance in 2009, the reference values of the coefficient of thermal conductivity in solid enclosing structures and elements are presented for buildings with srednoobemna internal temperature $\theta_{i} \geq 15^{\circ} \mathrm{C}[5]$.

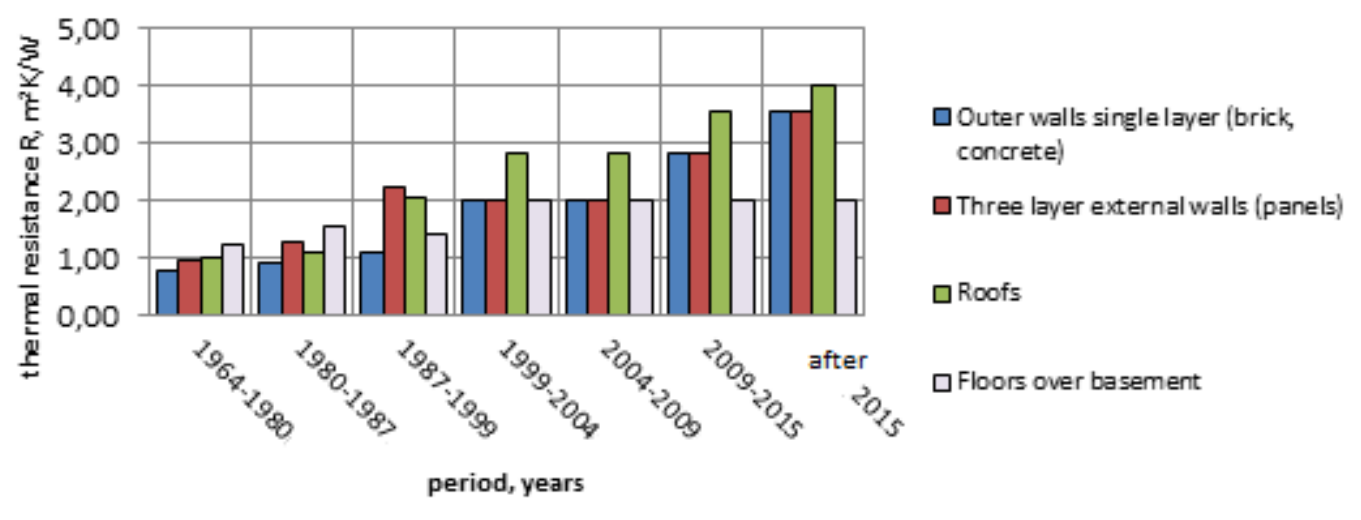

Figure 1. Requirements for the thermal resistance of the building envelope, $m^{2} \mathrm{~K} / \mathrm{W}$

In Figure 1 are presented dopustmite maximum thermal resistance of the building envelope under the existing regulatory framework $[1,2,5,7,8]$.

From the review of regulatory requirements relating to the design of the thermal insulation of buildings can be reported trend in the increase of the requirements for the thermal resistance of enclosing structures and elements of buildings in about five years, having decreased legally permitted maximum values of the coefficient of heat transfer. 


\section{REGULATORY REQUIREMENTS TO THE TRANSMITTANCE THROUGH THE TRANSPARENT ENCLOSURE STRUCTURES (WINDOWS AND DOORS) FOR BUILDINGS}

Table 3 presents the reference values of thermal transmittance of transparent enclosing structures (windows and doors) for residential and non-residential buildings under Decree №7 2004 on heat and energy savings in buildings (amend. 2009, 2010, 2013, 2015) [5].

The reference values of heat transfer coefficients of the types of windows, glass doors and windows refer to assembled construction element - window system constituting a set of individual and structural elements: windows, frames, friezes, seal, hardware, etc.

Table 3. Reference values of thermal transmittance of transparent enclosing structures (windows and doors) for residential and non-residential buildings

\begin{tabular}{|l|c|c|c|}
\hline \multicolumn{1}{|c|}{ Enclosing structures and elements } & \multicolumn{2}{c|}{$\mathrm{K} / \mathrm{m}^{2} \mathrm{~K}$} \\
\cline { 2 - 4 } & $\begin{array}{c}2004- \\
2009 \\
\theta_{i} \geq 19^{\circ} \mathrm{C}\end{array}$ & $\begin{array}{c}2009- \\
2015 \\
\theta_{i} \geq 15^{\circ} \mathrm{C}\end{array}$ & $\begin{array}{c}\text { after } \\
2015 \\
\theta_{\mathrm{i}} \geq 15^{\circ} \mathrm{C}\end{array}$ \\
\hline $\begin{array}{l}\text { External windows, glazed doors and windows with wings on } \\
\text { vertical and horizontal axis of rotation, with a frame of } \\
\text { extruded polyvinyl chloride (PVC) with three or more hollow } \\
\text { chambers }\end{array}$ & 2 & 1,7 & 1,4 \\
\hline $\begin{array}{l}\text { External windows, glazed doors and windows with wings on } \\
\text { vertical and horizontal axis of rotation, with aluminum frame } \\
\text { with interrupted thermal bridge }\end{array}$ & 2 & 2 & 1,7 \\
\hline $\begin{array}{l}\text { External windows, glazed doors and windows with wings on } \\
\text { vertical and horizontal axis of rotation, with wooden frames/ } \\
\text { skylights for each type of opening frame wood }\end{array}$ & 2 & $1,8 / 1,9$ & $1,6 / 1,8$ \\
\hline
\end{tabular}

\section{CONCLUSION}

The frequent changes in legislation related to energy efficiency in buildings created for different demands on thermo-physical properties of new and existing buildings.

From the review of regulatory requirements relating to the design of the thermal insulation of buildings, can be reported trend in increasing the requirements to the values of heat transfer coefficients in the surrounding structures and elements of buildings in about five years

The duration of each stage to introduce the buildings in operation, according to the legal basis for energy efficiency is bound by the procedures carried out by the municipalities for the award of the activities according to the Public Procurement Act and the applicable regulations [6]. Often it turns out that certain values of heat transfer coefficients of enclosing structures of buildings with insulation provided in the energy audit does not qualify after renovation of the building, due to changes in legislation.

The discrepancy of the reference values of these coefficients and the real after implementation of energy saving measures can be implemented with the prior increase the requirements in the energy efficiency assessment in comparison with the standards in the ordinance. Resolving this problem may occur after starting the detailed Analysis. 


\section{IRTTE Ipplied Reseirrches in Technics, Technologies and Bducition Journal of the Faculty of Technics and Technologies, Trakia University https://sites.google.com/a/trakia-uni.bg/artte/}

\section{REFERENCES}

[1] Decree № 1 of 5.01.1999 on the design of the thermal insulation of buildings issued by the Minister of Regional Development and Public Works, upgraded SG. 7 of 26.01.1999, effective from 27.04.1999, the * revoked. No.5 of 14.01.2005.

[2] Design standards of thermal insulation of buildings, in 1980, amended. 1987.

[3] Energy Efficiency Act (Updated - State Gazette No.98 of 14.11.2008, effective from 05.07.2013; amend. And suppl., SG. 59 of 07.05.2013).

[4] Ivanov K., Analysis of refrigerants relating to their impact on the environment, ARTTE Vol. 4, No. 2, 2016 ISSN 1314-8788 (print), ISSN 1314-8796 (online), 145-152.

[5] Ordinance №7 of 2004 on energy efficiency, heat and energy savings in buildings (Title. Amend. - State Gazette No.85 of 2009) Prom. - SG. no. 5 of 14.01.2005; amend. and suppl., SG. 85 of 27.10.2009; corr. SG. 88 of 06.11.2009; corr. SG. 92 of 20.11.2009; amend. and suppl., SG. 2 of 08.01.2010; amend. and suppl., SG. 80 from 13.09. 2013; amend. and suppl., SG. 93 of 25.10.2013, amended. and suppl., SG. 27 of 14.04.2015 d into force on 15.07.2015.

[6] Public Procurement Law Updated - State Gazette No.. 13 of 02.16.2016, effective from 15.04.2016.

[7] Temporary instruction design and implementation of the thermal insulation in building construction (in heated residential, public and industrial buildings), 1960.

[8] Thermal insulation in building construction. Design standards (in heated residential, public and industrial buildings), 1964, amended. 1969, amended. 1977.

[9] Zlatev Z., A. Dimitrova, S. Baycheva, M. Vasilev, Analysis of information processes in the production of yogurt, Journal of Innovation and entrepreneurship, year IV, vol.2, 2016, ISSN 1314-9180, pp.43-59.

[10] http://nisi.bg/ (available on 12.09.2016). 